\title{
Differential antitumor effects of vitamin D analogues on colorectal carcinoma in culture
}

\author{
J.M. WIERZBICKA ${ }^{1,2}$, A. BINEK ${ }^{2}$, T. AHRENDS ${ }^{2}$, J.D. NOWACKA ${ }^{2}$, A. SZYDŁOWSKA ${ }^{2}$, \\ Ł. TURCZYK ${ }^{2}$, T. WĄSIEWICZ ${ }^{1}$, P.M. WIERZBICKI ${ }^{1}$, R. SĄDEJ ${ }^{3}$, R.C. TUCKEY ${ }^{4}$,

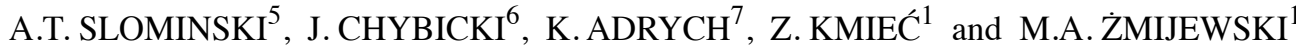

\begin{abstract}
${ }^{1}$ Department of Histology, Faculty of Medicine, Medical University of Gdańsk, Gdańsk; ${ }^{2}$ Students Scientific Association BIO-MED, Intercollegiate Faculty of Biotechnology of the University of Gdańsk and Medical University of Gdańsk, Gdańsk;

${ }^{3}$ Department of Molecular Enzymology, Intercollegiate Faculty of Biotechnology of the University of Gdańsk and Medical University of Gdańsk, Gdańsk, Poland; ${ }^{4}$ School of Chemistry and Biochemistry, The University of Western Australia, Crawley WA, Australia; ${ }^{5}$ Department of Dermatology, University of Alabama Birmingham, VA Medical Center, Birmingham, AL 35294, USA; ${ }^{6}$ Department of General Surgery, Hospital Ministry Internal Affairs, 80104 Gdańsk; ${ }^{7}$ Department of Hepatology and Gastroenterology, Faculty of Medicine, Medical University of Gdańsk, 80210 Gdańsk, Poland
\end{abstract}

Received May 4, 2015; Accepted June 15, 2015

DOI: 10.3892/ijo.2015.3088

\begin{abstract}
Colorectal cancer (CRC) is an emerging global problem with the rapid increase in its incidence being associated with an unhealthy lifestyle. Epidemiological studies have shown that decreased levels of vitamin $\mathrm{D}_{3}$ significantly increases the risk of CRC. Furthermore, negative effects of vitamin $\mathrm{D}_{3}$ deficiency can be compensated by appropriate supplementation. Vitamin $\mathrm{D}_{3}$ was shown to inhibit growth and induce differentiation of cancer cells, however, excessive vitamin $\mathrm{D}_{3}$ intake leads to hypercalcemia. Thus, development of efficient vitamin $\mathrm{D}_{3}$ analogues with limited impact on calcium homeostasis is an important scientific and clinically relevant task. The aims of the present study were to compare the antiproliferative potential of classic vitamin $\mathrm{D}_{3}$ metabolites $\left(1 \alpha, 25(\mathrm{OH})_{2} \mathrm{D}_{3}\right.$ and $\left.25(\mathrm{OH}) \mathrm{D}_{3}\right)$ with selected low calcemic analogues (calcipotriol and $20(\mathrm{OH}) \mathrm{D}_{3}$ ) on CRC cell lines and to investigate the expression of vitamin D-related genes in CRC cell lines and clinical samples. Vitamin $\mathrm{D}_{3}$ analogues exerted anti-proliferative effects on all CRC cell lines tested. Calcipotriol proved to be as potent as $1 \alpha, 25(\mathrm{OH})_{2} \mathrm{D}_{3}$ and had more efficacy than 20-hydroxyvitamin $\mathrm{D}_{3}$. In addition, the analogs tested effectively inhibited the formation of colonies in Matrigel. The expression of genes involved in $1 \alpha, 25(\mathrm{OH})_{2} \mathrm{D}_{3}$ signaling and metabolism varied in cell lines analysed, which explains in part their different sensitivities to the various
\end{abstract}

Correspondence to: Professor Michal A. Zmijewski, Department of Histology, Medical University of Gdańsk, ul. Debinki 1a, Room 230, 80-211 Gdańsk, Pomorskie, Poland

E-mail: mzmijewski@gumed.edu.pl

Key words: vitamin D, calcitriol, vitamin D analogues, colorectal cancer, vitamin D receptor analogues. In CRC biopsies, there was decreased VDR expression in tumor samples in comparison to the surgical margin and healthy colon samples $(\mathrm{P}<0.01)$. The present study indicates that vitamin $\mathrm{D}_{3}$ analogues which have low calcemic activity, such as calcipotriol or $20(\mathrm{OH}) \mathrm{D}_{3}$, are very promising candidates for CRC therapy. Moreover, expression profiling of vitamin D-related genes is likely to be a powerful tool in the planning of anticancer therapy. Decreased levels of VDR and increased CYP24A1 expression in clinical samples underline the importance of deregulation of vitamin D pathways in the development of CRC.

\section{Introduction}

Colorectal cancer (CRC) is the second among women and third among men of the most commonly diagnosed cancers in the world (1). A World Health Organization study from 2012 showed that colorectal cancer exceeds $1,360.500$ new cases every year worldwide (1). Furthermore, during the last 5 years, CRC incidence and mortality rates have increased in all developed countries. This appears to coincide with a diet change toward more fat- and carbohydrate-rich foods, and a deficiency in many nutrients including vitamin $\mathrm{D}$. This so-called urban-industrial or Western diet is highly based on processed foods (2).

Current colorectal cancer therapy is based on a combination of cytostatic drugs and surgery where applicable (3). The chemotherapeutic agent of choice is a 5-fluorouracil (5-FU), which is used for the treatment of both the advanced and early stages of colorectal cancer. Unfortunately, the effectiveness of 5-FU monotherapy of colorectal cancer is limited to only $10-15 \%$ of cases (4). Identification of compounds that can enhance the response to 5-FU is a key step in the development of combined chemotherapies. Several studies have shown that $1 \alpha, 25(\mathrm{OH})_{2} \mathrm{D}_{3}$ can be administered alone or in combination with other antitumor agents to enhance the effi- 
cacy of therapy. For example, $1 \alpha, 25(\mathrm{OH})_{2} \mathrm{D}_{3}$ downregulates the expression of thymidylate synthase (TS) and therefore promotes a cytotoxic response to 5-FU (5). Other studies have demonstrated that $1 \alpha, 25(\mathrm{OH})_{2} \mathrm{D}_{3}$ enhances cellular sensitivity of colorectal cancer cells to 5-FU through a calcium-sensing receptor $(5,6)$.

In humans, vitamin $\mathrm{D}_{3}$ is formed from 7-dehydrocholesterol (cholesta-5,7-dien-3 $\beta$-ol, 7DHC) in the basal layer of the epidermis. Initially, the B-ring of 7-DHC undergoes photolysis upon the exposure of skin to UV-B radiation, leading to formation of previtamin $D_{3}(7)$. Pre-vitamin $D_{3}$ then isomerizes to vitamin $\mathrm{D}_{3}$, or with further UV-B radiation to tachysterol $\left(\mathrm{T}_{3}\right)$ and lumisterol ${ }_{3}\left(\mathrm{~L}_{3}\right)$. Subsequent activation of vitamin $\mathrm{D}_{3}$ involves sequential 25- and 1- $\alpha$-hydroxylations of vitamin $\mathrm{D}_{3}$ (cholecalciferol) which can occur at both the systemic and local levels. In the liver, vitamin $\mathrm{D}_{3}$ is hydroxylated by mitochondrial and microsomal 25-hydroxylases (CYP27A1 and CYP2R1) to 25-hydroxyvitamin $\mathrm{D}_{3}\left(25(\mathrm{OH}) \mathrm{D}_{3}\right)$, also known as 25-hydroxycholecalciferol or calcifediol) (8). $25(\mathrm{OH}) \mathrm{D}_{3}$ is then hydroxylated in the kidneys by mitochondrial $1 \alpha$-hydroxylase (CYP27B1) (9) producing $1 \alpha, 25(\mathrm{OH})_{2} \mathrm{D}_{3}$ (calcitriol), the fully active form of vitamin $\mathrm{D}_{3}(10)$. A number of tissues and organs such as intestines and skin can also activate vitamin $\mathrm{D}_{3}$ through these two sequential hydroxylations (11). The activity of $25(\mathrm{OH}) \mathrm{D}_{3}$ and $1 \alpha, 25(\mathrm{OH})_{2} \mathrm{D}_{3}$ is limited by the 24-hydroxylase (CYP24A1), which initially transforms them to $24,25(\mathrm{OH})_{2} \mathrm{D}_{3}$ and $1,24,25(\mathrm{OH})_{3} \mathrm{D}_{3}$, respectively, prior to their further oxidation and cleavage of the side chain resultig in complete inactivation (12). Both $24,25(\mathrm{OH})_{2} \mathrm{D}_{3}$ and $1,24,25(\mathrm{OH})_{3} \mathrm{D}_{3}$ possess lower affinity for the vitamin $\mathrm{D}$ receptor (VDR) than $1,25(\mathrm{OH})_{2} \mathrm{D}_{3}(13)$. In addition, 7DHC, vitamin $\mathrm{D}_{2}$ and vitamin $\mathrm{D}_{3}$ can be metabolized by the steroidogenic enzyme, CYP11A1 (14-17). This enzyme catalyses a series of hydroxylations favoring C20, C22 and C23 but only results in cleavage of the side chain in the case 7DHC (18). CYP11A1, in combination with the classic vitamin D hydroxylases (CYP27A1, CYP27B1 and CYP24A1), has recently been shown to generate a series of vitamin D analogs in cells or tissues incubated ex vivo with vitamin D precursors (17,19-21), which are biologically active in cell culture (22) and in vivo (23) models $(19,21,24)$. Our previous studies showed that the initial and major product, $20(\mathrm{OH}) \mathrm{D}_{3}$, is non-calcemic $(25,26)$ with its biologically activity being defined by the nature of cellular target (21-23,25-28). Importantly, 20(OH) $\mathrm{D}_{3}$ displays anti-proliferative properties towards melanoma and other types of cancer $(26,31)$. Details of the pathways of vitamin D synthesis and metabolism is presented in Fig. 1.

The active form of vitamin $\mathrm{D}_{3}, 1 \alpha, 25(\mathrm{OH})_{2} \mathrm{D}_{3}$, plays a crucial role in calcium homeostasis, ensuring proper functioning of bones, muscles and the nervous system. In the colon it increases the absorption of calcium, in bones it stimulates release of calcium and phosphate, while in kidneys together with parathyroid hormone it regulates calcium reabsorption (32). In addition, $1 \alpha, 25(\mathrm{OH})_{2} \mathrm{D}_{3}$ is involved in regulating the immune system including reducing the inflammatory response (33) and influencing the growth and differentiation of mononuclear cells $(34,35)$. Several vitamin D analogs are already used for the treatment and/or prevention of various diseases such as rickets, osteoporosis and psoriasis (36). The importance of vitamin $\mathrm{D}$ is emphasized by a growing body of

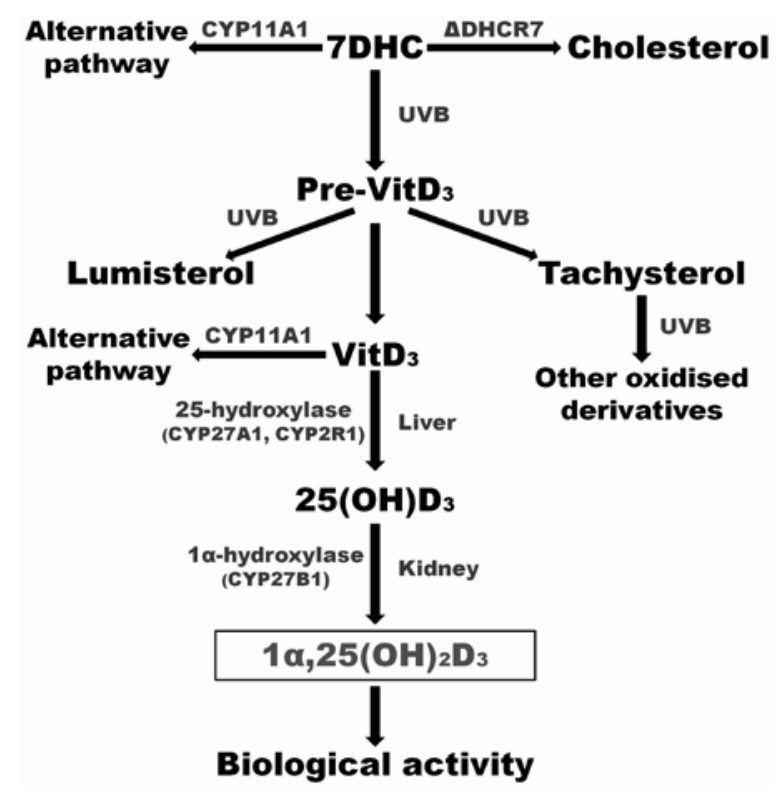

Figure 1. Synthesis, activation and metabolism of vitamin $\mathrm{D}_{3}$.

evidence that there is low $25(\mathrm{OH}) \mathrm{D}_{3}$ in the serum of patients with many types of cancer. Therefore, secosteroids (vitamin D and its derivatives), have potential applications in the treatment and/or prevention of several types of cancer, including breast, prostate, colorectal cancers and melanoma (37-39).

Active metabolites of $1 \alpha, 25(\mathrm{OH})_{2} \mathrm{D}_{3}$ are characterized by broad and diverse biological activities. After entering the cell, $1 \alpha, 25(\mathrm{OH})_{2} \mathrm{D}_{3}$ binds to the vitamin $\mathrm{D}$ receptor (VDR) which heterodimerizes with the 9-cis-retinoic acid receptor (retinoid X receptor, RXR). The VDR-RXR complex acts as a transcription factor, which recognizes a consensus DNA sequence, the vitamin D responsive element (VDRE), and regulates the expression of over 200 genes $(13,40)$. A widerange of studies show that $1 \alpha, 25(\mathrm{OH})_{2} \mathrm{D}_{3}$ regulates a number of genes involved in cell proliferation, DNA repair, differentiation, apoptosis and membrane transport. Among the most important ones are genes associated with vitamin $\mathrm{D}_{3}$ metabolism, as well as with calcium and phosphorus homeostasis (41). One of the most well-described activities of $1 \alpha, 25(\mathrm{OH})_{2} \mathrm{D}_{3}$ is the stimulation of the expression of the $C Y P 24 A 1$ gene (coding 24-hydroxylase) and the inhibition of the expression of the CYP27Al (25-hydroxylase) and CYP27B1 (1 $\alpha$-hydroxylase) genes (42). It is therefore likely that variations in the expression of genes involved in the regulation of $1 \alpha, 25(\mathrm{OH})_{2} \mathrm{D}_{3}$ activity could play an important role in determining susceptibility to CRC.

It has been suggested that $1 \alpha, 25(\mathrm{OH})_{2} \mathrm{D}_{3}$ can act via an alternative signaling pathway which involves binding to the endoplasmic reticulum protein PDIA3 (also known as ERp57) (43). PDIA3 protein belongs to the protein disulfide isomerases family (PDI) and is a disulfide oxidoreductase. PDIA3 is involved in the transport and post-translational modification of glycoproteins, in particular the heavy chains of the major histocompatibility complex type I (MHC I) and tyrosinase (44). In addition, calcium and potassium absorption in the colon is stimulated by $1 \alpha, 25(\mathrm{OH})_{2} \mathrm{D}_{3}$ via PDIA PI $_{3}$ It is also interesting that the PDIA3 contains a nuclear localization 


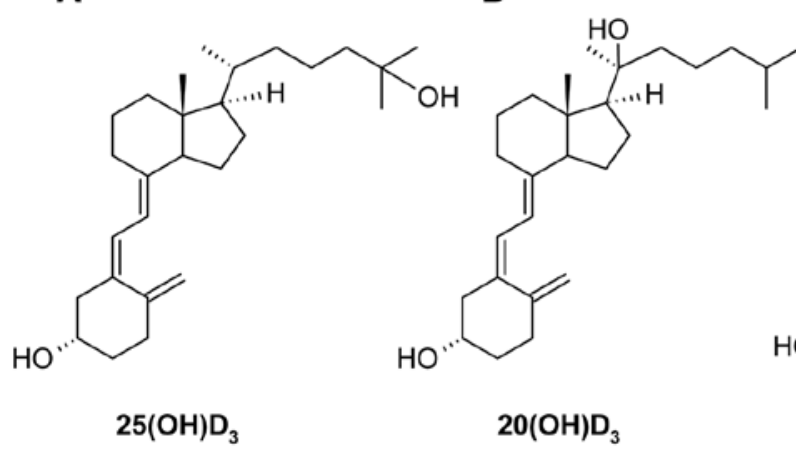<smiles>C=C1C(=CC=C2CCCC3(C)C2CC[C@H]3C(C)C)C[C@@H](O)CC1O</smiles><smiles>C=C1C(=CC=C2CCCC3(C)C2CCC3[C@@H](C)C=C[C@@H](O)C2CC2)C[C@@H](O)CC1O</smiles>

Figure 2. Structures of the vitamin D analogues used in the present study. (A) Calcifediol $\left(25(\mathrm{OH}) \mathrm{D}_{3}\right),(\mathrm{B}) 20(\mathrm{OH}) \mathrm{D}_{3},(\mathrm{C})$ calcitriol $\left(1,25(\mathrm{OH})_{2} \mathrm{D}_{3}\right),(\mathrm{D})$ calcipotriol.

signal sequence and a DNA binding domain, and interacts with the transcription factor, STAT3 (45). It has also been shown that under specific conditions PDIA3 can acts as a transcription factor or co-activator.

A number of studies support the potential preventative and therapeutic effects of vitamin $\mathrm{D}_{3}$, the precursor to $1 \alpha, 25(\mathrm{OH})_{2} \mathrm{D}_{3}$, for anticancer treatment. Unfortunately, administration of vitamin $\mathrm{D}_{3}$ at its effective therapeutic dose during treatment ( $>50,000$ units/day) is associated with a high probability of hypercalcaemia occurrence. This can cause such side-effects as nausea, vomiting and loss of appetite $(46,47)$, or be lethal depending on the anatomical site of calcium deposition. For this reason many laboratories have conducted studies on $1 \alpha, 25(\mathrm{OH})_{2} \mathrm{D}_{3}$ analogues with little or no impact on the calcium homeostasis, but still retaining therapeutically crucial properties (37). In the present study we have examined the effects of $1 \alpha, 25(\mathrm{OH})_{2} \mathrm{D}_{3}$, and selected analogues with low calcemic activity [calcipotriol, $25(\mathrm{OH}) \mathrm{D}_{3}, 20(\mathrm{OH}) \mathrm{D}_{3}$ ], on CRC cell lines (LoVo, HT29 and HCT116). We also examined the expression of key genes associated with $1 \alpha, 25(\mathrm{OH})_{2} \mathrm{D}_{3}$ activity and metabolism in CRC cell lines and colon cancer biopsies.

\section{Materials and methods}

Cell culture. The CRC cell lines LoVo (colon cancer), HT29 (colorectal adenocarcinoma) and HCT116 (colorectal carcinoma) were purchased from ATTC (Wesel, Germany). The HT29 cell lines were cultured in McCoy's medium, LoVo were cultured in Dulbecco's modified Eagle's medium (DMEM) and F-10 medium (ratio 1:1), while HCT116 were grown in DMEM only. All media were supplemented with $10 \%$ fetal bovine serum (FBS; Sigma) and 1\% PSA (penicillin-streptomycin-amphotericin B solution; Sigma). Cell cultures were maintained in a $37^{\circ} \mathrm{C}$ humidified atmosphere of $5 \% \mathrm{CO}_{2}$. Cells were passaged every 2-3 days.

Patients. The study was approved by the local ethics committee, and informed, written consent regarding the use of tissue was obtained before surgery or colonoscopy from all CRC patients and control individuals, respectively (48). The CRC specimens were received from the Department of General Surgery, Hospital Ministry Internal Affairs in Gdansk whereas the control samples were collected from the Department of Hepatology and Gastroenterology of the
Medical University of Gdansk (MUG). Clinical and demographical data were collected at the time of enrollment. The study included 20 patients with CRC (11 males and 9 females; mean age $67.2 \pm 10.8$ years; range, $50-87$ years). None of the CRC patients had a second neoplastic disease or had a history of previous chemo- or radiotherapy. Tumor CRC samples were collected from: rectum ( $n=7$ cases), sigmoid colon ( $n=5)$, transverse $(n=5)$ and 3 cases from cecum/ascending colon. The control group comprised 4 healthy individuals $(1$ males and 3 females; mean age 59 \pm 7.9 years; range, $54-65$ years) who underwent colonoscopy as a part of routine surveillance for CRC. None of the CRC patients or controls suffered from inflammatory bowel disease or had a family history of CRC. Patients were not on medications at the time of the investigation.

Vitamin $D$ and its analogues. Calcitriol $\left(1 \alpha, 25(\mathrm{OH})_{2} \mathrm{D}_{3}\right)$ and calcifediol $\left(25(\mathrm{OH}) \mathrm{D}_{3}\right)$ were obtained from Sigma (Poznań Poland). Calcipotriol was obtained from Pharmaceutical Research Institute (Warsaw, Poland). 20S-Hydroxyvitamin $\mathrm{D}_{3}\left(20(\mathrm{OH}) \mathrm{D}_{3} ;(3 \beta, 5 Z, 7 E)-9,10\right.$-secocholesta-5,7,10(19)trien-3,20-diol) was synthesized and purified as previously described (15). The structures of these secosteroids are presented in Fig. 2. They were dissolved in $99.5 \%$ ethanol and stored at $-20^{\circ} \mathrm{C}$. Their concentration was calculated using an extinction coefficient of $18,200 \mathrm{M}^{-1} \mathrm{~cm}^{-1}$ at $265 \mathrm{~nm}$. For in vitro use, dilutions were made in the same medium as those for cell culture. The highest final concentration of ethanol used in the present study never exceeded $0.2 \%$ and had no effect on cell growth.

Proliferation assays. The degree of proliferation of cells following treatment was measured using the 3-(4,5-dimethylthiazol-2-yl)-2,5-diphenyltetrazolium bromide assay (MTT) and the sulforhodamine B assay (SRB). Cells were seeded at a density of $\sim 7 \times 10^{3}$ (LoVo and HCT116) or $10^{4}$ (HT29) cells per $100 \mu 1 /$ well in 96-well plates in the appropriate growth medium, supplemented with $1 \%$ PSA and $2 \%$ charcoal-treated FBS, and allowed to attach for $24 \mathrm{~h}$ before treatment. The medium was replaced with fresh medium containing serial dilutions of $1 \alpha, 25(\mathrm{OH})_{2} \mathrm{D}_{3}$ or its analogues $(0.01 \mathrm{nM}-1 \mu \mathrm{M})$ in a volume of $100 \mu \mathrm{l} /$ well. The plates were incubated at $37^{\circ} \mathrm{C}$ for an additional $48 \mathrm{~h}$. For the MTT assay, $20 \mu 1$ of MTT $(5 \mathrm{mg} / \mathrm{ml})$ were added to each well. After incubation for $4 \mathrm{~h}$, the medium 
Table I. The PCR primers.

\begin{tabular}{|c|c|c|c|}
\hline GENE & Protein name & Primer sequence $\left(5^{\prime}-3^{\prime}\right)$ & Amplicon size (nt) \\
\hline \multirow[t]{2}{*}{ ACTB } & $\beta$-actin & GCTCGTCGTCGACAACGGCTC & \\
\hline & & CAAACATGATCTGGGTCATCTTCT & 353 \\
\hline \multirow[t]{2}{*}{ VDR } & Vitamin D receptor & CCAGTTCGTGTGAATGATGG & \\
\hline & & GTCGTCCATGGTGAAGGA & 384 \\
\hline \multirow[t]{2}{*}{ PDIA3 } & Protein disulfideisomerase-associated 3 & CTCCGACGTGCTAGAACTCA & \\
\hline & & CAGGTGTTAGTGTTGGCAGT & 204 \\
\hline \multirow[t]{2}{*}{ CYP24A1 } & 24-hydroxylase & GCAGCCTAGTGCAGATTT & \\
\hline & & ATTCACCCAGAACTGTTG & 335 \\
\hline \multirow[t]{2}{*}{ CYP24SV } & 24-hydroxylase & TCCTGAAGTTGCAGCTGGAGT & \\
\hline & & GAGCTCATCTATTCTGCCCATA & 215 \\
\hline \multirow[t]{2}{*}{ CYP2R1 } & 25-hydroxylase & AGAGACCCAGAAGTGTTCCAT & \\
\hline & & GTCTTTCAGCACAGATGAGGTA & 259 \\
\hline \multirow[t]{2}{*}{ CYP27B1 } & $1 \alpha$-hydroxylase & TGTTTGCATTTGCTCAGA & \\
\hline & & CCGGGAGAGCTCATACAG & 227 \\
\hline
\end{tabular}

was removed and $100 \mu \mathrm{l}$ of the solubilisation solution (1 M acidic isopropanol) was added to each well. After incubation for $5 \mathrm{~min}$ the absorbance was measured at $570 \mathrm{~nm}$ using a microplate reader. For the SRB assay, after incubation with the vitamin D analogs, $100 \mu 1$ of $10 \%$ trichloroacetic acid (TCA) was added to each well and plates were incubated for $1 \mathrm{~h}$ at $4^{\circ} \mathrm{C}$. Afterwards, the medium was removed and cells were washed 5 times with deionized water. Following overnight airdrying, $100 \mu \mathrm{l}$ of SRB solution [0.4\% (w/v) in $1 \%$ acetic acid] was added to each well. After incubation for $15 \mathrm{~min}$ plates were washed 5 times with $1 \%$ acetic acid and air-dried. The protein-bound dye was solubilised with a $10 \mathrm{mM}$ Tris-base solution ( $\mathrm{pH}$ 10.5). The absorbance of the dye was recorded at $570 \mathrm{~nm}$ with a microplate reader.

Cell growth in 3D matrigel. The three-dimensional cell growth assay was performed in a Matrigel Matrix (BD Bioscience, Heidelberg, Germany). Two drops of cell suspension in Matrigel ( $\sim 2 \mathrm{mg}$ of protein $/ \mathrm{ml}, \sim 1.5 \times 10^{3}$ cells $/ 40 \mu \mathrm{l}$ ) were added per well to a 12 -well tissue culture plate and plates incubated at $37^{\circ} \mathrm{C}$ for up to $30 \mathrm{~min}$ to allow the Matrigel to solidify. Wells were then submerged in growth medium supplemented with the relevant concentrations of $1 \alpha, 25(\mathrm{OH})_{2} \mathrm{D}_{3}$ or it analogs (final concentrations: $0.5,0.1$ or $0.2 \mu \mathrm{M}$ ). Growth medium was replaced every third day. Following 10 days of incubation representative pictures were taken and relative colony size was determined for 50 random colonies using ImageJ software. Each experiment was repeated at least four times. Due to the fast growth rate and the formation of crypt-like structures, only the inhibition of the formation of 'megacolonies' was compared.

Sample collection. CRC and control samples were collected as previously described with some modifications (48). Briefly, CRC and surgical margin tissue samples from each CRC patient collected during surgery were placed in sterile vials containing 5 volumes of RNAlater buffer (Ambion-Life Technologies, Grand Island, NY, USA), incubated for $6 \mathrm{~h}$ at $4^{\circ} \mathrm{C}$ and then stored at $-25^{\circ} \mathrm{C}$ until further analysis. The same procedure was also applied to control colon biopsies.

cDNA preparation and PCR assays. RNA was extracted using a Total RNA Mini Plus kit (A\&A Biotechnology, Gdynia, Poland) according to the manufacturer's protocol. Before the RNA isolation, tissue samples were homogenized in $2 \mathrm{ml}$ vials with the use of ceramic beads (Blirt-DNA Gdansk, Gdansk, Poland) in the MagNA Lyser apparatus (Roche Diagnostics Deutschland GmbH, Mannheim, Germany) for $45 \mathrm{sec}$ at $6,000 \mathrm{rpm}$. The concentration and purity of isolated RNA was measured using a NanoDrop ${ }^{\circledR}$ spectrophotometer. A total of $2 \mu \mathrm{g}$ of RNA were subjected to reverse transcription using a RevertAid $^{\mathrm{TM}}$ First Strand cDNA Synthesis kit (Thermo Fisher Scientific Inc., Waltham, MA, USA). All the primer sequences (Table I) were designed by the authors using Primer BLAST database and were purchased from Sigma-Aldrich (Munich, Germany). Quantification of the expression of genes of interest was carried out using the StepOnePlus ${ }^{\mathrm{TM}}$ Real-Time PCR System (Life Technologies-Applied Biosystems, Grand Island, NY, USA) with SYBR ${ }^{\circledR}$ Green as a fluorophore. $q$ PCR reactions were performed in a total volume of $20 \mu \mathrm{l}$ using Real-Time HS 2X PCR Master Mix SYBR ${ }^{\circledR}$ kit (A\&A Biotechnology), $2 \mu 1$ of cDNA diluted 4-fold and $200 \mathrm{nM}$ of each primer pair. The PCR conditions were: $95^{\circ} \mathrm{C}$ for 5 min followed by 40 cycles of denaturation for $15 \mathrm{sec}$ at $95^{\circ} \mathrm{C}$, annealing for $20 \mathrm{sec}$ at $59^{\circ} \mathrm{C}$, extension for $15-25 \mathrm{sec}$ at $72^{\circ} \mathrm{C}$, and fluorescence reading for $5 \mathrm{sec}$ at $77^{\circ} \mathrm{C}$. Dynamic melting curve analysis was performed for all reactions. All qPCR reactions were performed in duplicate and data were collected with a StepOnePlus ${ }^{\mathrm{TM}}$ software version 2.2 (Life Technologies). The expression of the genes was normalized by comparative $\Delta \Delta-C_{t}$ method, using $\beta$-actin as a housekeeping gene, followed by calibration (fold-change) 
Table II. The inhibition of $\mathrm{CRC}$ cell proliferation by $1,25(\mathrm{OH})_{2} \mathrm{D}_{3}$ and its analogs.

\begin{tabular}{lcccccccc}
\hline & \multicolumn{2}{c}{ LoVo } & & \multicolumn{2}{c}{ HT29 } & & \multicolumn{2}{c}{ HCT116 } \\
\cline { 2 - 3 } Compound $(n M)$ & MTT & SRB & & MTT & SRB & & MTT & SRB \\
\hline $1 \alpha, 25(\mathrm{OH})_{2} \mathrm{D}_{3}$ & 168 & 0.77 & & 57 & 196 & & 47 & 5.9 \\
Calcipotriol & 57 & 0.71 & & ND & 4.6 & & 5.3 & 3.7 \\
$25(\mathrm{OH}) \mathrm{D}_{3}$ & 6.6 & 35 & & 319 & 49 & & 457 & 243
\end{tabular}

The data are shown as $\mathrm{IC}_{50}$ values $(\mathrm{nM})$ representing the concentration of the secosteroid which causes a 50\% decrease in cell proliferation as measured by MTT and SRB assays. ND, not determined.

to normalized expression data of samples from controls $($ ratio=1).

Western blotting. Cells were scraped and lysed in the presence of ice-cold Laemmli buffer supplemented with protease inhibitor cocktail. Protein concentrations were determined by the Bradford assay. An equal amount of protein from each sample $(50 \mu \mathrm{g})$ was loaded per lane, proteins were separated by SDS-PAGE and then transferred onto an Immun-Blot ${ }^{\mathrm{TM}}$ PVDF membrane (Bio-Rad Laboratories, Hercules, CA, USA) The membranes were incubated with primary antibodies: anti-VDR (polyclonal, 1:1,000; Sigma-Aldrich, SAB2102673), anti-CYP24A1 (polyclonal, 1:500; Santa Cruz Biotechnology, sc-66851) or HRP conjugated anti- $\beta$-actin antibody (monoclonal, 1:5,000; Santa Cruz Biotechnology, sc-47778) overnight at $4^{\circ} \mathrm{C}$. After three washes in TBST, secondary mouse anti-rabbit antibodies conjugated to horseradish peroxidase (1:10,000; Santa Cruz Biotechnology, sc-2537) were added and following incubation for $1 \mathrm{~h}$ at room temperature. Blots were developed with SuperSignal ${ }^{\circledR}$ West Pico chemiluminescent substrate (Thermo Fisher Scientific) according to the manufacturer's protocol.

Statistical analysis. Data were analyzed with the Student's t-test (for two groups) or one-way analysis of variance and appropriate post hoc test (the ANOVA Kruskal-Wallis test for comparison of several groups), using Statistica (StatSoft Inc., Tulsa, OK, USA) or GraphPad Prism v6.03 (GraphPad Software, San Diego, CA, USA). For tissue samples, the MannWhitney U test of Kruskal-Wallis ANOVA was applied since the qPCR results for those specimens did not pass the omnibus test of D'Agostino and Pearson (49). Such procedures allowed the comparison of each experimental group with the control. Spearman's test was applied to check the association of paired data (correlation test). The data are presented as mean \pm SD or median value with range (min-max). Results were considered statistically significant at $\mathrm{P}<0.05$ and are marked in the figures as: ${ }^{* * * *} \mathrm{P}<0.0001 ;{ }^{* * *} \mathrm{P}<0.001 ;{ }^{* *} \mathrm{P}<0.01 ;{ }^{*} \mathrm{P}<0.05$.

\section{Results}

The effect of $1 \alpha, 25(\mathrm{OH})_{2} \mathrm{D}_{3}$ and its analogs on the proliferation of CRC cell lines. The effects of vitamin $\mathrm{D}$ analogues on the inhibition of the proliferation of CRC cell lines, LoVo, HT29 and HCT116, were assessed by means of MTT and SRB assays
(Fig. 3 and Table I). As shown by the MTT assay, the inhibitory effect of $1 \alpha, 25(\mathrm{OH})_{2} \mathrm{D}_{3}$ treatment was similar for LoVo and HT29 cell lines (Fig. 3A and C). A significant decrease in cell growth compared to vehicle-treated cells $(\mathrm{P}<0.001$ for LoVo and $\mathrm{P}<0.0001$ for HT29 cell line) was seen with $1 \mu \mathrm{M}$ $1 \alpha, 25(\mathrm{OH})_{2} \mathrm{D}_{3}$ (Fig. 3D and F), but not for HCT116 cells where the inhibition of growth did not reach statistical significance (Fig. 3E). The $\mathrm{IC}_{50}$ value of $1,25(\mathrm{OH})_{2} \mathrm{D}_{3}$ for LoVo $(168 \mathrm{nM})$ with the MTT assay was slightly higher than that for HT29 cells $(57 \mathrm{nM})$ and HCT116 cells $(47 \mathrm{nM})$ (Table II).

The $\mathrm{IC}_{50}$ values measured for $1,25(\mathrm{OH})_{2} \mathrm{D}_{3}$ by the SRB assay differed to those measured using the MTT assay, presumably due to the different biochemical parameters measured by these assays, the activity of NAD(P)H-dependent cellular oxidoreductase enzymes in the case of MTT and cellular protein content in the case of SRB. The proliferation of the LoVo cell line (Fig. 3A) measured with the SRB assay was significantly $(\mathrm{P}<0.0001)$ decreased with $1.0 \mathrm{nM} 1,25(\mathrm{OH})_{2} \mathrm{D}_{3}$ compared to vehicle-treated control cells, with the calculated $\mathrm{IC}_{50}$ being $0.77 \mathrm{nM}$ (Table III). A statistically significant decrease in the proliferation of HCT116 and HT29 cells by $1,25(\mathrm{OH})_{2} \mathrm{D}_{3}$ was also seen using the SRB assay (Fig. 3B and C) although $\mathrm{IC}_{50}$ values were considerably higher than for the LoVo cells (5.9 and $196 \mathrm{nM}$, respectively (Table II).

Calcipotriol, a low-calcemic analogue of vitamin D (39), proved to be the most potent inhibitor of proliferation of the three analogs tested using both the MTT and SRB assays on the colorectal cancer cell lines (Fig. 3M-R and Table II). With the SRB assay, calcipotriol caused significant inhibition of the proliferation of the LoVo, HCT116 and HT29 cells, compared to vehicle-treated cells, at concentrations as low as 1,10 and $10 \mathrm{nM}$, respectively (Fig. 3M-O).

The potency of $25(\mathrm{OH}) \mathrm{D}_{3}$ relative to $1,25(\mathrm{OH})_{2} \mathrm{D}_{3}$ varied for the LoVo and HCT116 cells depending on whether the MTT or SRB assay was used (Fig. 3). It should be noted that colon cells express CYP27B1 and are capable of transforming $25(\mathrm{OH}) \mathrm{D}_{3}$ to $1,25(\mathrm{OH})_{2} \mathrm{D}_{3}(20)$. With both the MTT and SRB assays, $25(\mathrm{OH}) \mathrm{D}_{3}$ displayed a lower potency than $1,25(\mathrm{OH})_{2} \mathrm{D}_{3}$ for inhibiting the proliferation of HCT116 cells (Table II), likely reflecting the relatively poor ability of these cells to activate this secosteroid by $1 \alpha$-hydroxylation (Table II).

Effect of $1 \alpha, 25(\mathrm{OH})_{2} \mathrm{D}_{3}$ and its analogues on CRC cell lines colony formation in three-dimensional Matrigel. The LoVo and HT29 cell lines were used to test the effects of $1 \alpha, 25(\mathrm{OH})_{2} \mathrm{D}_{3}$ and its two low- or non-calcemic analogues, calcipotriol and $20(\mathrm{OH}) \mathrm{D}_{3}$, respectively, on cell growth and colony formation in three-dimensional Matrigel. Our initial tests with the HCT116 cell line showed that these cells grew too slowly in Matrigel to perform comparable experiments so this particular cell line was excluded from the Matrigel assays. In control experiments (without treatment), the majority of the LoVo and HT29 cells gave rise to large colonies with complex structure 'megacolonies', while the remaining $~ 10 \%$ of cells formed small colonies with limited growth. Due to the faster growth rate with the formation of crypt-like structures, only the inhibition of the formation of 'megacolonies' was analyzed.

In agreement with the results of the MTT and SRB assays, vitamin $\mathrm{D}$ analogues significantly diminished cell proliferation as shown by the decrease in both size and the number of 

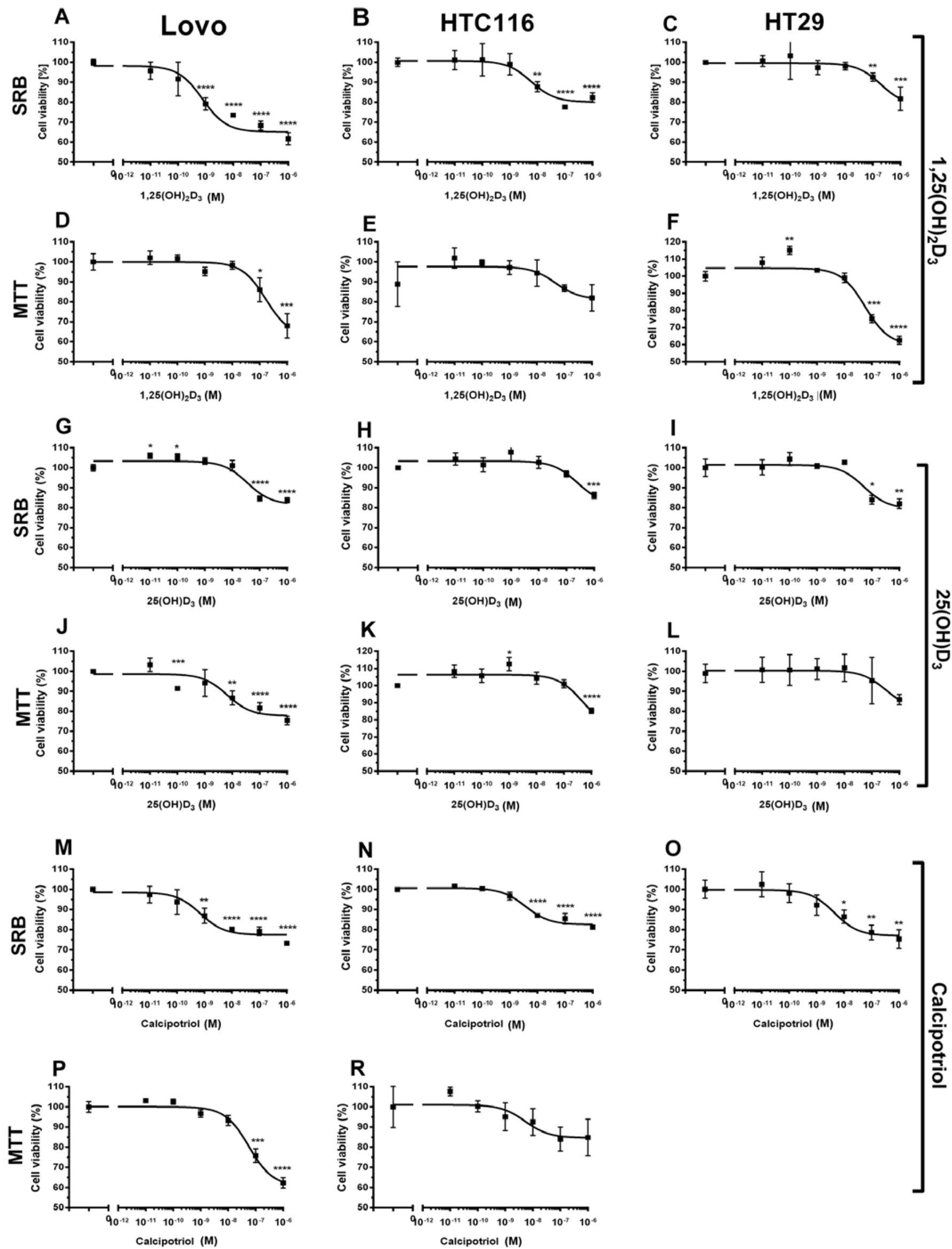

Figure 3. The effect of $1,25(\mathrm{OH})_{2} \mathrm{D}_{3}, 25(\mathrm{OH}) \mathrm{D}_{3}$ and calcipotriol on the proliferation of CRC cell lines. The effects of $(\mathrm{A}-\mathrm{F}) 1,25(\mathrm{OH})_{2} \mathrm{D}_{3},(\mathrm{G}-\mathrm{L}) 25(\mathrm{OH}) \mathrm{D}_{3}$ and (M-R) calcipotriol on proliferation of LoVo, HCT116 and HT29 cells were measured by MTT and SRB assays. Cells were incubated in medium (see Materials and methods) with varying concentrations $\left(10^{-6}\right.$ to $\left.10^{-11} \mathrm{M}\right)$ of the vitamin $\mathrm{D}$ analogue for $48 \mathrm{~h}$ prior to the SRB and MTT assays. Significance compared to the vehicle-treated control: $\mathrm{P}<0.05,{ }^{* *} \mathrm{P}<0.01,{ }^{* * *} \mathrm{P}<0.001,{ }^{* * * *} \mathrm{P}<0.0001$; mean $\pm \mathrm{SD}$. 

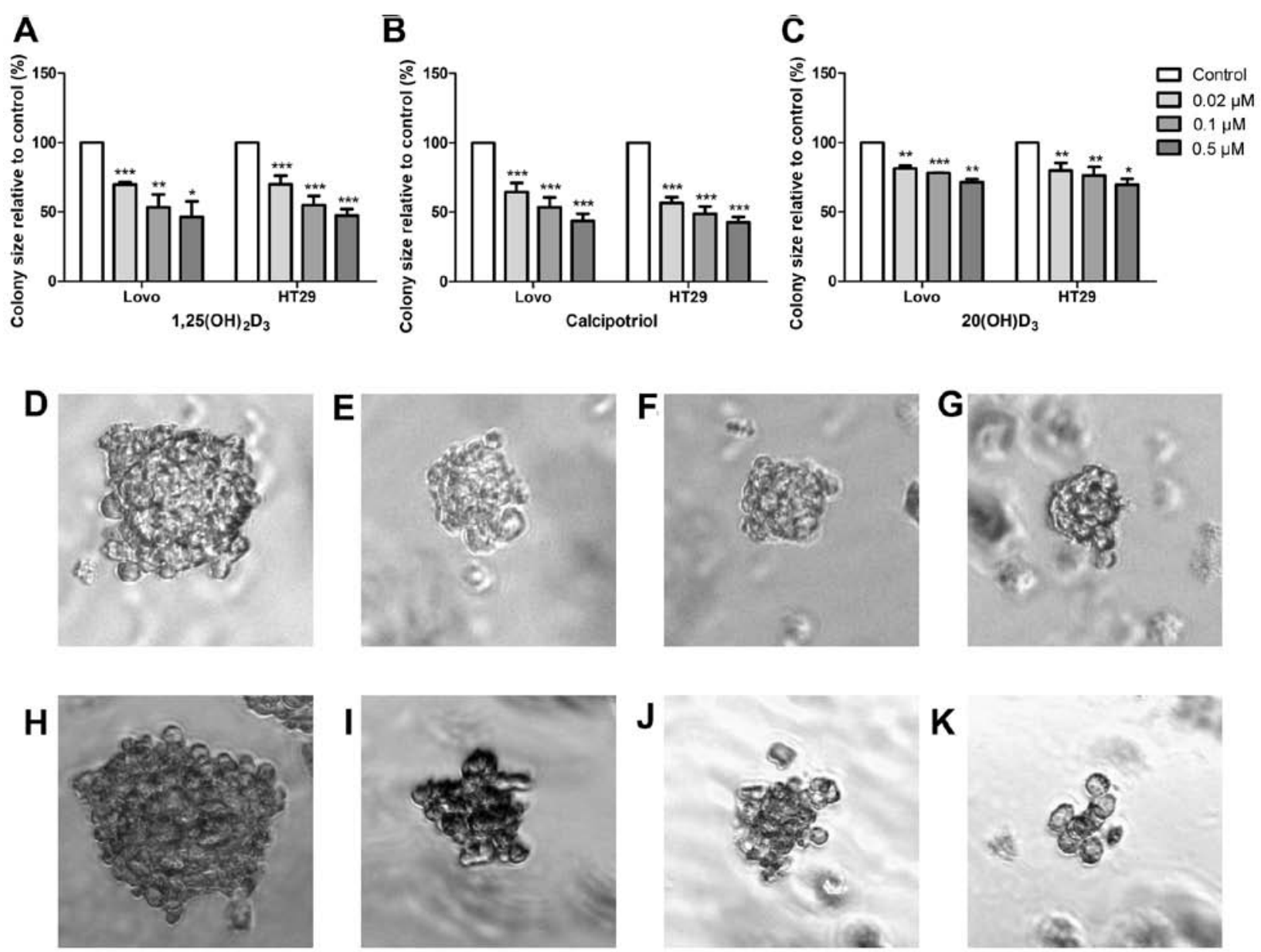

Figure 4. The effect of $1 \alpha, 25(\mathrm{OH})_{2} \mathrm{D}_{3}$, calcipotriol and $20(\mathrm{OH}) \mathrm{D}_{3}$ on $\mathrm{CRC}$ colony formation in Matrigel. Cells in Matrigel were incubated with varying concentrations $(0.02,0.1$ or $0.5 \mu \mathrm{M})$ of $(\mathrm{A}) 1 \alpha, 25(\mathrm{OH})_{2} \mathrm{D}_{3}$, (B) calcipotriol or $(\mathrm{C}) 20(\mathrm{OH}) \mathrm{D}_{3}$ for 10 days. Light microscopy of representative 'megacolonies' formed in 10 days following the addition of $(\mathrm{D}-\mathrm{G}) 1 \alpha, 25(\mathrm{OH})_{2} \mathrm{D}_{3}$ and $(\mathrm{H}-\mathrm{K})$ calcipotriol on LoVo cells are also shown. Original magnification, $\mathrm{x} 100$. The concentrations of $1 \alpha, 25(\mathrm{OH})_{2} \mathrm{D}_{3}$ and $25(\mathrm{OH}) \mathrm{D}_{3}$ used were $0 \mu \mathrm{M}$ (controls, D and $\left.\mathrm{H}\right) ; 0.02 \mu \mathrm{M}$ (E and I); $0.1 \mu \mathrm{M}$ (F and J) and $0.5 \mu \mathrm{M}(\mathrm{G}$ and $\mathrm{K})$. Significance compared to the control: ${ }^{*} \mathrm{P}<0.05,{ }^{* *} \mathrm{P}<0.01,{ }^{* * *} \mathrm{P}<0.001$.

the colonies formed in a presence of the three analogues tested (Fig. 4). Over the limited range of concentrations tested $(20-500 \mathrm{nM})$, the potency of $1,25(\mathrm{OH})_{2} \mathrm{D}_{3}$, calcipotriol and $20(\mathrm{OH}) \mathrm{D}_{3}$ were reasonably similar with a significant reduction in colony size seen in both LoVo and HT29 cells for all three analogs at a concentration of $20 \mathrm{nM}$. The magnitude of the inhibition (efficacy) varied between the three analogs. Calcipotriol caused the greatest inhibition $(\sim 57 \%)$ at the highest concentration tested $(500 \mathrm{nM})$, while $1,25(\mathrm{OH})_{2} \mathrm{D}_{3}$ caused $\sim 53 \%$ inhibition and $20(\mathrm{OH}) \mathrm{D}_{3} \sim 28 \%$ inhibition at this concentration, for both cell lines.

$1,25(\mathrm{OH})_{2} \mathrm{D}_{3}$ modulates the expression of some of the genes involved in vitamin $D$ metabolism and signalling. The expression levels of several genes encoding proteins inolved in vitamin D signalling (VDR and PDIA3) and metabolism (CYP24A1 and its splice variant, CYP24SV; CYP27B1 and CYP2R1) were compared by real-time PCR (qPCR) (Fig. 5). Basal levels of transcripts of CYP24A1 and its splice variant, CYP24SV, were strongly elevated in the HT29 and HCT116 cell lines compared to LoVo cells (Fig. 5A and C). $1,25(\mathrm{OH})_{2} \mathrm{D}_{3}$ caused a marked and statistically significant elevation of transcript levels for both CYP24A1 and CYP24SV, most pronounced in the LoVo cell line (3,100-fold for CYP24A1 and 1,200-fold for CYP24SV) due to the low basal level of expression. The stimulation of CYP24A1 expression by $1,25(\mathrm{OH})_{2} \mathrm{D}_{3}$ was confirmed at the protein level for all three cell lines (Fig. 3A, bottom panels) although the magnitude of the stimulation appeared less for the LoVo cells than at the transcript level.

For the three cell lines, expression of CYP2R1 transcripts was significantly downregulated by $1,25(\mathrm{OH})_{2} \mathrm{D}_{3}$ only in the HT29 cells (6.6-fold, $\mathrm{P}<0.05)$ where the basal level was higher than in the other cells (Fig. $5 \mathrm{E}$ ). $1,25(\mathrm{OH})_{2} \mathrm{D}_{3}$ did not alter the level of transcripts for CYP27B1 in any of the three cell lines (Fig. 5F). Basal levels of CYP27B1 transcripts were significantly lower in HT29 and HCT116 cells than in LoVo cells. For PDIA3 transcript, basal levels were significantly higher in HT29 cells than in LoVo cells (Fig. 5D). 1,25(OH $)_{2} \mathrm{D}_{3}$ significantly decreased the the expression of PDIA3 in LoVo and HT29 cells, but not in the HCT116 cell line. $1,25(\mathrm{OH})_{2} \mathrm{D}_{3}$ significantly increased the expression of the VDR at the mRNA level in only the LoVo cells. Basal expression was also significantly higher in LoVo cells than in the HT29 or HCT116 cells (Fig. 5B). Consistent with the results at the transcript level, marginal increases at best were seen for VDR expression at the protein level following treatment with $1,25(\mathrm{OH})_{2} \mathrm{D}_{3}$. The highest expression of VDR was in the HT29 cells (Fig 3B, 
A
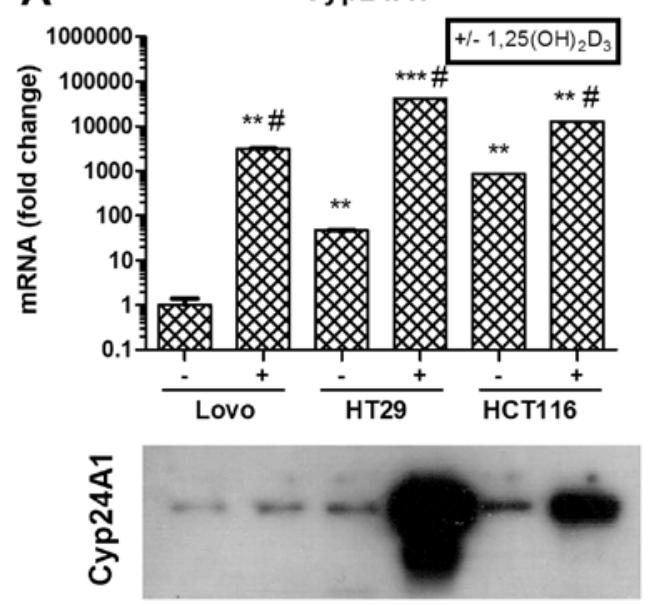

菒

$C$

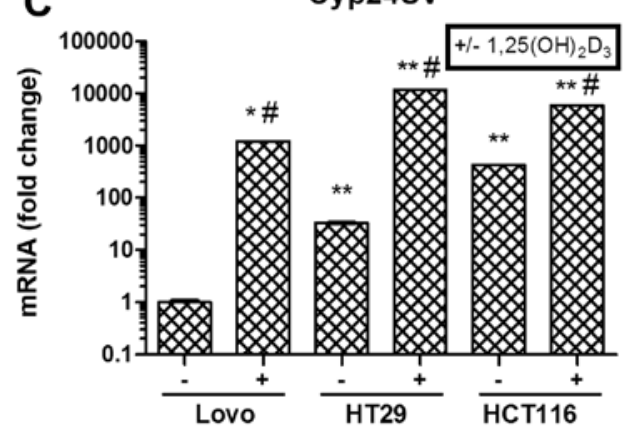

E

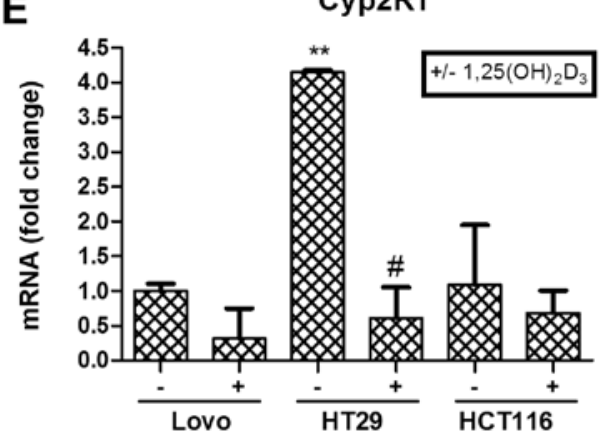

B
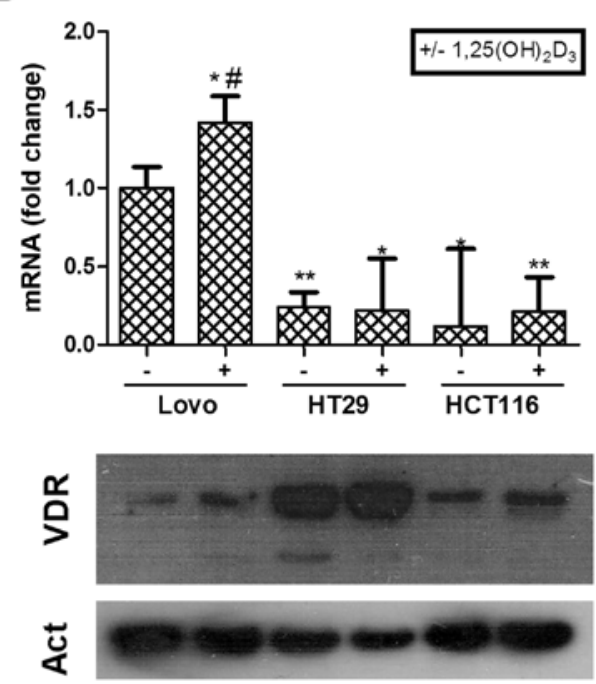

PDIA3

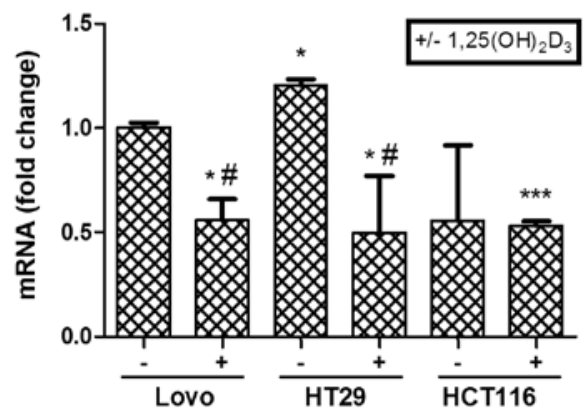

Cyp27B1

F

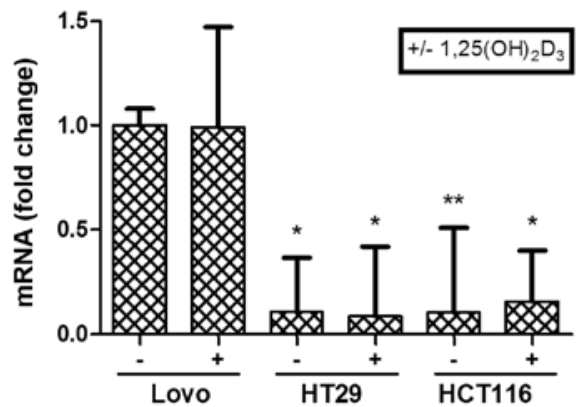

Figure 5. The effects of $1,25(\mathrm{OH})_{2} \mathrm{D}_{3}$ on the expression of genes involved in vitamin $\mathrm{D}_{3}$ signaling and metabolism. CRC cell lines were incubated with $0.1 \mu \mathrm{M}$ $1,25(\mathrm{OH})_{2} \mathrm{D}_{3}$ for $24 \mathrm{~h}$ and the expression of 24-hydroxylase (CYP24Al gene) (A), vitamin D receptor (VDR gene) (B), splicing variant of 24-hydroxylase (CYP24SV gene) (C), protein disulfide isomerase (PDIA3 gene) (D), 25-hydroxylase (CYP2R1 gene) (E) and 1 $\alpha$-hydroxylase (CYP27B1 gene) (F) was analysed by real-time PCR (qPCR). Data were normalized relative to $\beta$-actin mRNA and further normalized against the basal expression in LoVo cells. CYP24A1 (A, lower panel) and vitamin $\mathrm{D}$ receptor $(\mathrm{B}$, lower panel) proteins were measured by western blotting, with $\beta$-actin used as a control. The data are presented are mean \pm SEM. Significance level relative to the LoVo cell basal expression: ${ }^{*} \mathrm{P}<0.05,{ }^{* *} \mathrm{P}<0.01,{ }^{* * *} \mathrm{P}<0.001$. Significance level relative to the untreated control for each cell line is indicated as ${ }^{*} \mathrm{P}<0.05$.

lower panels). The splice variant of the VDR protein (lower band) was observed most prominently in untreated HT29 cells.

Expression of VDR and CYP24A1 genes in CRC biopsies. The expression of VDR and CYP24Al genes in CRC biopsies and control samples were assessed by qPCR (Fig. 6). Matched tumor-surgical margin biopsies from $20 \mathrm{CRC}$ patients were analyzed in comparison to healthy mucosal colon biopsies from 4 individuals who underwent routine colonoscopy. There was a significant decrease in the expression of VDR in tumor
CRC samples in comparison to the surgical margin and healthy control specimens (Fig. 6A and C). Analysis of the clinical data revealed that there was no association between the VDR expression level and either gender, age, tumor progression (Fig. 6C), G staging or metastasis presence.

The highest expression of CYP24A1 was observed in surgical margin specimens in comparison to both tumor and control samples $(\mathrm{P}<0.0001$; Fig. 6B). No correlation between CYP24A1 expression and gender or age was found. When the clinical data were taken into consideration, we observed 

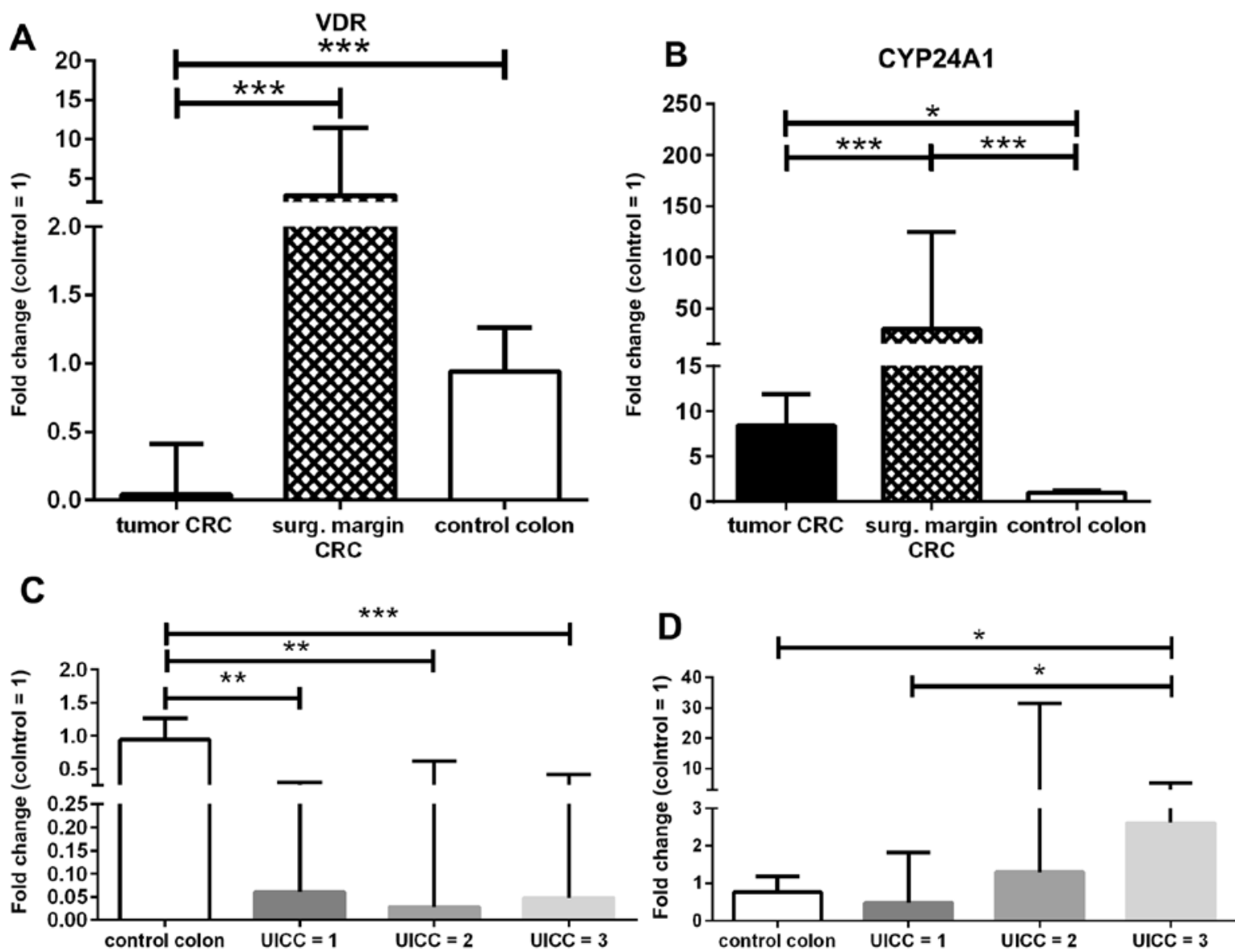

Figure 6. Analysis of VDR and CYP24A1 expression at the mRNA level in clinical samples. Boxes represent median values; (A) VDR and (B) CYP24A1 levels in tumor CRC (black bars) and surgical margin samples (chequered bars) from 20 CRC patients were compared to colon samples from control patients (white bars, set to 1). CRC samples were divided by UICC grades (Union for International Cancer Control) for comparison to control samples for (C) VDR and (D) CYP24A1. Mann-Whitney U tests were applied; significance level, indicated by horizontal lines: ${ }^{*} \mathrm{P}<0.05,{ }^{* *} \mathrm{P}<0.01,{ }^{* * *} \mathrm{P}<0.001$.

that CYP24A1 expression was associated with tumor location (proximal to distal colon) $(r s=0.48 ; \mathrm{P}<0.02)$. Despite the general decrease in CYP24A1 mRNA in tumor specimens compared to the surgical margin, we found increased expression in higher (Stage I to III, UICC grading 1 to 3) developed tumors (rs=0.36; $\mathrm{P}<0.05$, Spearman's test, $\mathrm{P}=0.001$; KruskalWallis ANOVA; Fig. 6D). Finally, CYP24A1 expression in tumor tissue was correlated with VDR mRNA levels ( $\mathrm{rs}=0.57$, $\mathrm{P}<0.05$; Spearman's test; Fig. 6C and D).

\section{Discussion}

The first aim of the study was to investigate the effects of $1,25(\mathrm{OH})_{2} \mathrm{D}_{3}$ and its low-calcemic analogues (particularly calcipotriol and $\left.20(\mathrm{OH}) \mathrm{D}_{3}\right)$ on the proliferation of $\mathrm{CRC}$ cell lines. Calcipotriol has a 100- to 200-fold lower effect on calcium metabolism than $1,25(\mathrm{OH})_{2} \mathrm{D}_{3}(51)$, while $20(\mathrm{OH}) \mathrm{D}_{3}$ is non-calcemic at concentration $\leq 60 \mu \mathrm{g} / \mathrm{kg}$ (26). Three different $\mathrm{CRC}$ cell lines were chosen, representing colon cancer (LoVo), colorectal adenocarcinoma (HT29) and colorectal carcinoma (HCT116). The LoVo cell line is well differentiated, HT29 cells are moderately differentiated, while the HCT116 cell line is poorly differentiated (52).

Overall, our results show that calcipotriol has similar or greater potency to $1,25(\mathrm{OH})_{2} \mathrm{D}_{3}$ using MTT, SRB and Matrigel assays of cell proliferation. $25(\mathrm{OH}) \mathrm{D}_{3}$ was generally found to be less potent than $1,25(\mathrm{OH})_{2} \mathrm{D}_{3}$ but there were exceptions such as in the MTT assay on LoVo cells and the SRB assay on HT29 cells. It should be noted that while it is generally accepted that $25(\mathrm{OH}) \mathrm{D}_{3}$ exerts its action following its conversion to $1,25(\mathrm{OH})_{2} \mathrm{D}_{3}$ by CYP27B1, which is present in the colon, recent studies indicate that it may have distinct actions independent of $1,25(\mathrm{OH})_{2} \mathrm{D}_{3}(53)$.

The treatment of the LoVo and HT29 cell lines with $1,25(\mathrm{OH})_{2} \mathrm{D}_{3}$, calcipotriol or $20(\mathrm{OH}) \mathrm{D}_{3}$ in Matrigel caused a statistically significant inhibition of colony size at a concentration of only $20 \mathrm{nM}$, with stronger inhibition at $500 \mathrm{nM}$. Since matrigel resembles a three dimensional basement membrane complex into which cells can invade, proliferate and grow (54), these results indicate that the low calcemic analogs of vitamin $\mathrm{D}_{3}$ tested in the present study are worthy of future in vivo testing.

The SRB assay results indicate that the LoVo cell line is the most sensitive to the vitamin $\mathrm{D}$ analogues examined (lowest $\mathrm{IC}_{50}$ values), while the HTC116 cell line was the most resistant. Thus, it might be speculated that moderately differentiated cells (LoVo and HT29 cell lines) are more sensitive to vitamin D analogs compared with poorly differentiated HCT116 cells. However, this correlation does not hold for the MTT assay results. 
The dose-dependent, anti-proliferative activity of $1 \alpha, 25(\mathrm{OH})_{2} \mathrm{D}_{3}$ on human CRC cells has been previously reported by other researchers $(35,55-59)$. For instance, treatment of the colon cancer cell line, Caco-2, with vitamin $\mathrm{D}_{3}$ analogs resulted in growth inhibition by $20-40 \%$ (at a concentration of $0.01 \mu \mathrm{M})(60)$. This is in general agreement with our results with calcipotriol and $1,25(\mathrm{OH})_{2} \mathrm{D}_{3}$, but we observed that $\mathrm{IC}_{50}$ values varied between the different cell lines studied. Thus, the observed differences in sensitivity of CRC to vitamin $\mathrm{D}$ analogues may dependent on the unique properties of the cancer cells $(37,38)$, including the degree of expression of VDR and CYP24A1 (49), as well as on the molecular structure of the vitamin $\mathrm{D}_{3}$ analogue. It has recently been suggested that epigenetic changes may influence the expression of crucial genes which encode proteins involved in the metabolism of vitamin D, such as CYP24A1 (61). According to the classical pathway, vitamin $\mathrm{D}_{3}$ acts through the VDR, as supplementation of VDR knockout animals with vitamin $\mathrm{D}_{3}$ analogues does not protect them from tumor development (62). Our results indicate that the CRC cell lines studied differ in their constitutive level of VDR mRNA and protein. The LoVo cell line showed the highest relative level of VDR mRNA whereas the HT29 cell line showed the highest concentration of protein. Thus, the relatively high level of VDR mRNA in the LoVo cell line did not correlate with the highest level of its protein product. In fact, the LoVo cell line showed the lowest concentration of VDR protein in comparison to HT29 and HTC116 cells. These inconsistencies can be explained by the recent report showing that the VDR can be regulated at the post-translational level via proteosomal degradation in a cell-type specific manner (63).

Notably, epidemiological studies show that vitamin D deficiency (64), as well as specific polymorphisms in the VDR gene $(65,66)$, are strong prognostic factors for development and severity of CRC. It is also well established that the VDR is expressed by normal colon epithelial cells, but its expression is decreased during the progression of colon cancer (67). A similar reverse correlation between VDR expression and the aggressiveness of the tumor was reported for human melanomas $(68,69)$. Our results reveal that there is a significant downregulation of VDR expression in patients with CRC at stages I to III. Another interesting observation is the comparatively high level of VDR transcript expression in surgical margin specimens in comparison to both tumor and control samples of healthy colon mucosa. A correlation between tumor progression and CYP24A1 expression at the mRNA level was observed in the CRC biopsies. Our results therefore indicate that changes in expression of the above genes may provide useful information as a prognostic predictor for CRC metastasis.

The responsiveness of the CRC cell lines to vitamin $\mathrm{D}_{3}$ analogues may also be affected by their metabolism and inactivation. Our in vitro results show that there is correlation between the expression of VDR, and to a lesser degree CYP24A1, at the mRNA and protein levels in CRC cell lines treated with $1,25(\mathrm{OH})_{2} \mathrm{D}_{3}$. This is in an agreement with the data of Höbaus et al (61) who showed a very high level of expression of CYP24A1 in HT29 cells and suggested that this expression is connected with methyltransferase and some histone deacetylase inhibitors in a cell line-dependent manner. Furthermore, the present study shows that basal expression of CYP24A1 and CYP24SV (isoform lacking mitochondrial translocation signal (50) are highly upregulated at the mRNA and protein levels in HT29 and HCT116 cell lines compared to the LoVo cell line. Increased expression of CYP24A1 in cancer cells may attenuate the effects of $1 \alpha, 25(\mathrm{OH})_{2} \mathrm{D}_{3}$ on growth inhibition and differentiation. Stimulation by $1 \alpha, 25(\mathrm{OH})_{2} \mathrm{D}_{3}$ significantly increased the expression of CYP24A1 in LoVo, HT29 and HCT116 cell lines. It has been shown before that induction of CYP24A1 expression by $1 \alpha, 25(\mathrm{OH})_{2} \mathrm{D}_{3}$ treatment is more pronounced in responsive CRCs and melanomas in comparison to resistant ones $(56,70,71)$. Furthermore, CRC cell lines (HT29 and HCT116) with the highest basal expression of CYP24A1 at the transcript level were shown to be less responsive to vitamin $\mathrm{D}$ treatment, which is consistent with other studies (35). However, this correlation is not so clear at the protein level. The role of CYP24A1 in tumor biology may be complex as indicated by clinicopathological studies on patients with melanoma (72).

Although, catabolism of vitamin D by CYP24A1 is considered as a major regulatory mechanism controlling $25(\mathrm{OH}) \mathrm{D}_{3}$ and $1,25(\mathrm{OH})_{2} \mathrm{D}_{3}$ concentrations, expression of other genes involved in vitamin D metabolism may influence the responsiveness of cancer cells to the treatment (57). Recently, it was shown that CYP2R1 and not CYP27A1 is the major vitamin D 25-hydroxylase (73). We have found that that the treatment of HT2 2 cells with $1,25(\mathrm{OH})_{2} \mathrm{D}_{3}$ significantly decreased the expression of CYP2R1 at the mRNA level but the small decreases in the other cell lines did not reach statistical significance. Notably, in the responsive HT29 cells, the basal level of CYP2R1 mRNA was 4 times higher than in the HTC116 or LoVo cells.

$1,25(\mathrm{OH})_{2} \mathrm{D}_{3}$ had no effect on the expression of 1 $\alpha$-hydroxylase (CYP27B1) at the mRNA level in any of the three cell lines analysed. It is well established now that CYP27B1 is expressed at extra-renal sites such as normal colon, brain, placenta, pancreas, lymph nodes and skin (74). Our data show that basal expression of CYP27B1 at the mRNA level is higher in LoVo cells compared to the HT29 and HCT116 cell lines. Higher CYP27B1 expression has previously been reported in well-to-moderately differentiated states of colon cancer compared to poorly differentiated colon carcinomas (75-77). A similar reverse correlation between CYP27B1 expression and tumor progression and aggressiveness was found in melanomas and ovarian cancer $(78,79)$. Increased expression of CYP27B1 in cancer tissues may convey some chemoprevention to these cancers due to increased conversion of $25(\mathrm{OH}) \mathrm{D}_{3}$ of $1,25(\mathrm{OH})_{2} \mathrm{D}_{3}$. Notably, the LoVo cells which show the highest expression of CYP27B1, display the lowest $\mathrm{IC}_{50}$ of the three cell lines for the inhibition of proliferation by $25(\mathrm{OH}) \mathrm{D}_{3}$.

The VDR is not the only target for active forms of vitamin $\mathrm{D}$ in the cells. For instance, vitamin $\mathrm{D}_{3}$ may exert some non-genomic actions mediated by PDIA3 (80). The most resistant cell line, HCT116, showed the lowest basal level of PDIA3 mRNA and the treatment with $1,25(\mathrm{OH})_{3} \mathrm{D}_{3}$ did not affect its expression. In contrast, treatment of LoVo and HT29 cells with $1,25(\mathrm{OH})_{2} \mathrm{D}_{3}$ resulted in a significant decrease of PDIA3 mRNA.

It was shown that products of a novel CYP11A1-dependent pathway of vitamin D metabolism, such as $20(\mathrm{OH}) \mathrm{D}_{3}$ (which 
the present study shows to inhibit CRC proliferation) and $20,23(\mathrm{OH})_{2} \mathrm{D}_{3}$, can act as antagonists or inverse agonists on ROR $\alpha$ and ROR $\gamma$ (27). These findings may not only give new insights into local (skin) or systemic regulation of genes by vitamin $\mathrm{D}$ metabolites, but could also explain the pleiotropic activity of $20(\mathrm{OH}) \mathrm{D}_{3}$ and $20,23(\mathrm{OH})_{2} \mathrm{D}_{3}$, without the calcemic effects (22) typically seen for classical VDR ligands (65). It should be noted that $20(\mathrm{OH}) \mathrm{D}_{3}$ has been detected in human serum (19) and epidermis (21) indicating that it may have a physiological role as an endogenous regulator.

In summary, CRC is becoming a major problem in modern societies with an aging population as its occurrence correlates with a lack of physical activity and unhealthy dietary habits, as well as with vitamin D deficiency $(61,81)$. Thus, there is an urgent need for an inexpensive, easily available, safe and effective prevention and treatment for CRC. The present study indicates that low calcemic calcipotriol or non-calcemic $20(\mathrm{OH}) \mathrm{D}_{3}$, with proven anti-proliferative activity, may replace $1 \alpha, 25(\mathrm{OH})_{2} \mathrm{D}_{3}$ in the treatment of CRC, preferably in combination with other cytostatic agents. Additionally, our results indicate that profiling the expression of genes involved in vitamin D signaling and metabolism, particularly VDR and CYP24A1, may provide a powerful tool for the planning of vitamin $\mathrm{D}_{3}$ analogue-based anticancer therapy.

\section{Acknowledgements}

The present study was supported in part by grant AR052190, 1R01AR056666-01A2 and R21AR066505-01A1 from the NIH/NIAMS (A.T.S.). Students Scientific Association BIO-MED (J.W., A.B., T.A., J.N., A.S., Ł.T., M.A.Z.) was awarded with a grant by the Polish Genetic Society.

\section{References}

1. Ferlay J, Soerjomataram I, Dikshit R, Eser S, Mathers C, Rebelo M, Parkin DM, Forman D and Bray F: Cancer incidence and mortality worldwide: Sources, methods and major patterns in GLOBOCAN 2012. Int J Cancer 136: E359-E386, 2015.

2. López-Gómez M, Malmierca E, de Górgolas M and Casado E: Cancer in developing countries: The next most preventable pandemic. The global problem of cancer. Crit Rev Oncol Hematol 88: 117-122, 2013.

3. Wolpin BM and Mayer RJ: Systemic treatment of colorectal cancer. Gastroenterology 134: 1296-1310, 2008.

4. Johnston PG and Kaye S: Capecitabine: A novel agent for the treatment of solid tumors. Anticancer Drugs 12: 639-646, 2001.

5. Liu G, Hu X and Chakrabarty S: Vitamin D mediates its action in human colon carcinoma cells in a calcium-sensing receptordependent manner: Downregulates malignant cell behavior and the expression of thymidylate synthase and survivin and promotes cellular sensitivity to 5-FU. Int J Cancer 126: 631-639, 2010.

6. Milczarek M, Psurski M, Kutner A and Wietrzyk J: Vitamin D analogs enhance the anticancer activity of 5-fluorouracil in an in vivo mouse colon cancer model. BMC Cancer 13: 294, 2013.

7. Holick MF, Frommer JE, McNeill SC, Richtand NM, Henley JW and Potts JT Jr: Photometabolism of 7-dehydrocholesterol to previtamin D3 in skin. Biochem Biophys Res Commun 76: 107-114, 1977.

8. Holick MF, DeLuca HF and Avioli LV: Isolation and identification of 25-hydroxycholecalciferol from human plasma. Arch Intern Med 129: 56-61, 1972.

9. Holick MF, Schnoes HK, DeLuca HF, Gray RW, Boyle IT and Suda T: Isolation and identification of 24,25-dihydroxycholecalciferol, a metabolite of vitamin D made in the kidney. Biochemistry 11: 4251-4255, 1972.
10. Holick MF, Schnoes HK, DeLuca HF, Suda T and Cousins RJ: Isolation and identification of 1,25-dihydroxycholecalciferol. A metabolite of vitamin D active in intestine. Biochemistry 10: 2799-2804, 1971.

11. Hewison M, Zehnder D, Chakraverty R and Adams JS: Vitamin D and barrier function: A novel role for extra-renal 1 alpha-hydroxylase. Mol Cell Endocrinol 215: 31-38, 2004.

12. Tieu EW, Tang EKY, Tuckey RC and Adams JS: Kinetic analysis of human CYP24A1 metabolism of vitamin D via the C24-oxidation pathway. FEBS J 281: 3280-3296, 2014.

13. Haussler MR, Whitfield GK, Haussler CA, Hsieh JC, Thompson PD, Selznick SH, Dominguez CE and Jurutka PW: The nuclear vitamin D receptor: Biological and molecular regulatory properties revealed. J Bone Miner Res 13: 325-349, 1998.

14. Slominski A, Zjawiony J, Wortsman J, Semak I, Stewart J, Pisarchik A, Sweatman T, Marcos J, Dunbar C and C Tuckey R: A novel pathway for sequential transformation of 7-dehydrocholesterol and expression of the P450scc system in mammalian skin. Eur J Biochem 271: 4178-4188, 2004.

15. Slominski A, Semak I, Zjawiony J, Wortsman J, Li W, Szczesniewski A and Tuckey RC: The cytochrome P450scc system opens an alternate pathway of vitamin D3 metabolism. FEBS J 272: 4080-4090, 2005.

16. Guryev O, Carvalho RA, Usanov S, Gilep A and Estabrook RW: A pathway for the metabolism of vitamin D3: Unique hydroxylated metabolites formed during catalysis with cytochrome P450scc (CYP11A1). Proc Natl Acad Sci USA 100: 14754-14759, 2003.

17. Slominski A, Semak I, Wortsman J, Zjawiony J, Li W, Zbytek B and Tuckey RC: An alternative pathway of vitamin D metabolism. Cytochrome P450scc (CYP11A1)-mediated conversion to 20-hydroxyvitamin D2 and 17,20-dihydroxyvitamin D2. FEBS J 273: 2891-2901, 2006.

18. Slominski AT, Li W, Kim TK, Semak I, Wang J, Zjawiony JK and Tuckey RC: Novel activities of CYP11A1 and their potential physiological significance. J Steroid Biochem Mol Biol 151: 25-37, 2015.

19. Slominski AT, Kim TK, Shehabi HZ, Semak I, Tang EK, Nguyen MN, Benson HA, Korik E, Janjetovic Z, Chen J, et al: In vivo evidence for a novel pathway of vitamin $\mathrm{D}_{3}$ metabolism initiated by P450scc and modified by CYP27B1. FASEB J 26: 3901-3915, 2012.

20. Slominski AT, Kim TK, Shehabi HZ, Tang EK, Benson HA, Semak I, Lin Z, Yates CR, Wang J, Li W, et al: In vivo production of novel vitamin D2 hydroxy-derivatives by human placentas, epidermal keratinocytes, Caco-2 colon cells and the adrenal gland. Mol Cell Endocrinol 383: 181-192, 2014.

21. Slominski AT, Janjetovic Z, Kim TK, Wasilewski P, Rosas S, Hanna S, Sayre RM, Dowdy JC, Li W and Tuckey RC: Novel non-calcemic secosteroids that are produced by human epidermal keratinocytes protect against solar radiation. J Steroid Biochem Mol Biol 148: 52-63, 2015.

22. Slominski AT, Kim TK, Li W, Yi AK, Postlethwaite A and Tuckey RC: The role of CYP11A1 in the production of vitamin $\mathrm{D}$ metabolites and their role in the regulation of epidermal functions. J Steroid Biochem Mol Biol 144: 28-39, 2014.

23. Slominski A, Janjetovic Z, Tuckey RC, Nguyen MN, Bhattacharya KG, Wang J, Li W, Jiao Y, Gu W, Brown M, et al: 20S-hydroxyvitamin $\mathrm{D}_{3}$, noncalcemic product of CYP11A1 action on vitamin $\mathrm{D}_{3}$, exhibits potent antifibrogenic activity in vivo. J Clin Endocrinol Metab 98: E298-E303, 2013.

24. Slominski AT, Kim TK, Chen J, Nguyen MN, Li W, Yates CR, Sweatman T, Janjetovic Z and Tuckey RC: Cytochrome P450sccdependent metabolism of 7-dehydrocholesterol in placenta and epidermal keratinocytes. Int J Biochem Cell Biol 44: 2003-2018, 2012.

25. Slominski AT,Kim TK, Janjetovic Z, Tuckey RC, Bieniek R, Yue J, Li W, Chen J, Nguyen MN, Tang EK, et al: 20-Hydroxyvitamin D2 is a noncalcemic analog of vitamin D with potent antiproliferative and prodifferentiation activities in normal and malignant cells. Am J Physiol Cell Physiol 300: C526-C541, 2011.

26. Slominski AT, Janjetovic Z, Fuller BE, Zmijewski MA, Tuckey RC, Nguyen MN, Sweatman T, Li W, Zjawiony J, Miller D, et al: Products of vitamin D3 or 7-dehydrocholesterol metabolism by cytochrome P450scc show anti-leukemia effects, having low or absent calcemic activity. PLoS One 5: e9907, 2010.

27. Slominski AT, Kim TK, Takeda Y, Janjetovic Z, Brozyna AA, Skobowiat C, Wang J, Postlethwaite A, Li W, Tuckey RC, et al: ROR $\alpha$ and ROR $\gamma$ are expressed in human skin and serve as receptors for endogenously produced noncalcemic 20-hydroxyand 20,23-dihydroxyvitamin D. FASEB J 28: 2775-2789, 2014. 
28. Zbytek B, Janjetovic Z, Tuckey RC, Zmijewski MA, Sweatman TW, Jones E, Nguyen MN and Slominski AT: 20-Hydroxyvitamin D3, a product of vitamin D3 hydroxylation by cytochrome $\mathrm{P} 450 \mathrm{scc}$, stimulates keratinocyte differentiation. J Invest Dermatol 128: 2271-2280, 2008.

29. Slominski AT, Janjetovic Z, Kim TK, Wright AC, Grese LN, Riney SJ, Nguyen MN and Tuckey RC: Novel vitamin D hydroxyderivatives inhibit melanoma growth and show differential effects on normal melanocytes. Anticancer Res 32: 3733-3742, 2012.

30. Janjetovic Z, Brozyna AA, Tuckey RC, Kim TK, Nguyen MN Jozwicki W, Pfeffer SR, Pfeffer LM and Slominski AT: High basal NF- $\kappa \mathrm{B}$ activity in nonpigmented melanoma cells is associated with an enhanced sensitivity to vitamin D3 derivatives. Br J Cancer 105: 1874-1884, 2011.

31. Wang J, Slominski A, Tuckey RC, Janjetovic Z, Kulkarni A, Chen J, Postlethwaite AE, Miller D and Li W: 20-hydroxyvitamin $\mathrm{D}_{3}$ inhibits proliferation of cancer cells with high efficacy while being non-toxic. Anticancer Res 32: 739-746, 2012.

32. Holick MF: Vitamin D and bone health. J Nutr 126 (Suppl): 1159S-1164S, 1996.

33. Hayes CE, Nashold FE, Spach KM and Pedersen LB: The immunological functions of the vitamin D endocrine system. Cell Mol Biol (Noisy-le-grand) 49: 277-300, 2003.

34. Pálmer HG, Sánchez-Carbayo M, Ordóñez-Morán P, Larriba MJ, Cordón-Cardó C and Muñoz A: Genetic signatures of differentiation induced by 1alpha,25-dihydroxyvitamin $\mathrm{D}_{3}$ in human colon cancer cells. Cancer Res 63: 7799-7806, 2003.

35. Shabahang M, Buras RR, Davoodi F, Schumaker LM, Nauta RJ and Evans SR: 1,25-Dihydroxyvitamin $\mathrm{D}_{3}$ receptor as a marker of human colon carcinoma cell line differentiation and growth inhibition. Cancer Res 53: 3712-3718, 1993.

36. Leyssens C, Verlinden L and Verstuyf A: The future of vitamin D analogs. Front Physiol 5: 122, 2014.

37. Hansen CM, Hamberg KJ, Binderup $\mathrm{E}$ and Binderup L: Seocalcitol (EB 1089): A vitamin D analogue of anti-cancer potential. Background, design, synthesis, pre-clinical and clinical evaluation. Curr Pharm Des 6: 803-828, 2000.

38. Slominski AT and Carlson JA: Melanoma resistance: A bright future for academicians and a challenge for patient advocates. Mayo Clin Proc 89: 429-433, 2014.

39. Bikle DD: Vitamin D: An ancient hormone. Exp Dermatol 20 7-13, 2011.

40. Brown AJ, Dusso A and Slatopolsky E: Vitamin D. Am J Physiol 277: F157-F175, 1999.

41. Ebert R, Schütze N, Adamski J and Jakob F: Vitamin D signaling is modulated on multiple levels in health and disease. Mol Cell Endocrinol 248: 149-159, 2006.

42. Whitfield GK, Jurutka PW, Haussler CA, Hsieh JC, Barthel TK, Jacobs ET, Encinas Dominguez C, Thatcher ML and Haussler MR: Nuclear vitamin D receptor: structure-function, molecular control of gene transcription, and novel bioactions. In: Vitamin D. 2nd edition. Feldman D, Pike JW and Glorieux FH (eds). Elsevier Academic Press, Oxford, pp219-261, 2005.

43. Khanal R and Nemere I: Membrane receptors for vitamin D metabolites. Crit Rev Eukaryot Gene Expr 17: 31-47, 2007.

44. Bouvier M: Accessory proteins and the assembly of human class I MHC molecules: A molecular and structural perspective. Mol Immunol 39: 697-706, 2003.

45. Eufemi M, Coppari S, Altieri F, Grillo C, Ferraro A and Turano C: ERp57 is present in STAT3-DNA complexes. Biochem Biophys Res Commun 323: 1306-1312, 2004.

46. Ozkan B, Hatun S and Bereket A: Vitamin D intoxication. Turk J Pediatr 54: 93-98, 2012

47. Wierzbicka J, Piotrowska A and Żmijewski MA: The renaissance of vitamin D. Acta Biochim Pol 61: 679-686, 2014.

48. Wierzbicki PM, Adrych K, Kartanowicz D, Stanislawowski M, Kowalczyk A, Godlewski J, Skwierz-Bogdanska I, Celinski K, Gach T, Kulig J, et al: Underexpression of LATS1 TSG in colorectal cancer is associated with promoter hypermethylation. World J Gastroenterol 19: 4363-4373, 2013.

49. Wierzbicki PM, Klacz J, Rybarczyk A, Slebioda T, Stanislawowski M, Wronska A, Kowalczyk A, Matuszewski M and Kmiec Z: Identification of a suitable qPCR reference gene in metastatic clear cell renal cell carcinoma. Tumour Biol 35: 12473-12487, 2014.
50. Ren S, Nguyen L, Wu S, Encinas C, Adams JS and Hewison M Alternative splicing of vitamin D-24-hydroxylase: A novel mechanism for the regulation of extrarenal 1,25-dihydroxyvitamin D synthesis. J Biol Chem 280: 20604-20611, 2005.

51. Binderup L: Comparison of calcipotriol with selected metabolites and analogues of vitamin D3: Effects on cell growth regulation in vitro and calcium metabolism in vivo. Pharmacol Toxicol 72: 240-244, 1993.

52. Ieta K, Tanaka F, Haraguchi N, Kita Y, Sakashita H, Mimori K, Matsumoto T, Inoue H, Kuwano H and Mori M: Biological and genetic characteristics of tumor-initiating cells in colon cancer. Ann Surg Oncol 15: 638-648, 2008.

53. Tuohimaa P, Wang JH, Khan S, Kuuslahti M, Qian K, Manninen T, Auvinen P, Vihinen M and Lou YR: Gene expression profiles in human and mouse primary cells provide new insights into the differential actions of vitamin D3 metabolites. PLoS One 8: e75338, 2013

54. Benton G, Arnaoutova I, George J, Kleinman HK and Koblinski J: Matrigel: From discovery and ECM mimicry to assays and models for cancer research. Adv Drug Deliv Rev 79-80: 3-18, 2014.

55. Evans SR, Schwartz AM, Shchepotin EI, Uskokovic M and ShchepotinIB:Growthinhibitoryeffectsof 1,25-dihydroxyvitamin $\mathrm{D}_{3}$ and its synthetic analogue, $1 \alpha, 25$-dihydroxy-16-ene-23yne26,27-hexafluoro-19-nor-cholecalcifero 1 (Ro 25-6760), on a human colon cancer xenograft. Clin Cancer Res 4: 2869-2876, 1998.

56. Cross HS, Bises G, Lechner D, Manhardt T and Kállay E: The Vitamin D endocrine system of the gut - its possible role in colorectal cancer prevention. J Steroid Biochem Mol Biol 97: $121-128,2005$

57. Milczarek M, Filip-Psurska B, Swietnicki W, Kutner A and Wietrzyk J: Vitamin D analogs combined with 5-fluorouracil in human HT-29 colon cancer treatment. Oncol Rep 32: 491-504, 2014.

58. Milczarek M, Rosinska S, Psurski M, Maciejewska M, Kutner A and Wietrzyk J: Combined colonic cancer treatment with vitamin D analogs and irinotecan or oxaliplatin. Anticancer Res 33: 433-444, 2013

59. Tanaka Y, Bush KK, Klauck TM and Higgins PJ: Enhancement of butyrate-induced differentiation of HT-29 human colon carcinoma cells by 1,25-dihydroxyvitamin D3. Biochem Pharmacol 38: 3859-3865, 1989.

60. Cross HS, Farsoudi KH and Peterlik M: Growth inhibition of human colon adenocarcinoma-derived Caco-2 cells by 1,25-dihydroxyvitamin D3 and two synthetic analogs: Relation to in vitro hypercalcemic potential. Naunyn Schmiedebergs Arch Pharmacol 347: 105-110, 1993

61. Höbaus J, Fetahu IS, Khorchide M, Manhardt T and Kallay E: Epigenetic regulation of the 1,25-dihydroxyvitamin $\mathrm{D}_{3}$ 24-hydroxylase (CYP24A1) in colon cancer cells. J Steroid Biochem Mol Biol 136: 296-299, 2013.

62. Mordan-McCombs S, Valrance M, Zinser G, Tenniswood M and Welsh J: Calcium, vitamin D and the vitamin D receptor: Impact on prostate and breast cancer in preclinical models. Nutr Rev 65 : S131-S133, 2007

63. Peleg S and Nguyen CV: The importance of nuclear import in protection of the vitamin $\mathrm{D}$ receptor from polyubiquitination and proteasome-mediated degradation. J Cell Biochem 110: 926-934, 2010.

64. Zgaga L, Theodoratou E, Farrington SM, Din FV, Ooi LY, Glodzik D, Johnston S, Tenesa A, Campbell H and Dunlop MG: Plasma vitamin D concentration influences survival outcome after a diagnosis of colorectal cancer. J Clin Oncol 32: 2430-2439, 2014.

65. Köstner K, Denzer N, Müller CS, Klein R, Tilgen W and Reichrath J: The relevance of vitamin D receptor (VDR) gene polymorphisms for cancer: A review of the literature. Anticancer Res 29: 3511-3536, 2009.

66. Laczmanska I, Laczmanski L, Bebenek M, Karpinski P, Czemarmazowicz H, Ramsey D, Milewicz A and Sasiadek MM: Vitamin D receptor gene polymorphisms in relation to the risk of colorectal cancer in the Polish population. Tumour Biol 35: 12397-12401, 2014.

67. Vandewalle B, Adenis A, Hornez L, Revillion F and Lefebvre J: 1,25-dihydroxyvitamin $\mathrm{D}_{3}$ receptors in normal and malignant human colorectal tissues. Cancer Lett 86: 67-73, 1994.

68. Brożyna AA, Jozwicki W, Janjetovic Z and Slominski AT: Expression of vitamin $D$ receptor decreases during progression of pigmented skin lesions. Hum Pathol 42: 618-631, 2011. 
69. Brożyna AA, Jóźwicki W and Slominski AT: Decreased VDR expression in cutaneous melanomas as marker of tumor progression: New data and analyses. Anticancer Res 34: 2735-2743, 2014.

70. Reichrath J, Rech M, Moeini M, Meese E, Tilgen W and Seifert M: In vitro comparison of the vitamin D endocrine system in $1,25(\mathrm{OH})_{2} \mathrm{D}_{3}$-responsive and -resistant melanoma cells. Cancer Biol Ther 6: 48-55, 2007.

71. Albertson DG, Ylstra B, Segraves R, Collins C, Dairkee SH, Kowbel D, Kuo WL, Gray JW and Pinkel D: Quantitative mapping of amplicon structure by array CGH identifies CYP24 as a candidate oncogene. Nat Genet 25: 144-146, 2000.

72. Brożyna AA, Jochymski C, Janjetovic Z, Jóźwicki W, Tuckey RC and Slominski AT: CYP24A1 expression inversely correlates with melanoma progression: Clinic-pathological studies. Int J Mol Sci 15: 19000-19017, 2014.

73. Flanagan JN, Young MV, Persons KS, Wang L, Mathieu JS, Whitlatch LW, Holick MF and Chen TC: Vitamin D metabolism in human prostate cells: Implications for prostate cancer chemoprevention by vitamin D. Anticancer Res 26: 2567-2572, 2006

74. Zehnder D, Bland R, Williams MC, McNinch RW, Howie AJ, Stewart PM and Hewison M: Extrarenal expression of 25-hydroxyvitamin d(3)-1 alpha-hydroxylase. J Clin Endocrinol Metab 86: 888-894, 2001

75. Cross HS, Bareis P, Hofer H, Bischof MG, Bajna E, Kriwanek S Bonner E and Peterlik M: 25-Hydroxyvitamin $\mathrm{D}_{3}$-1alphahydroxylase and vitamin $\mathrm{D}$ receptor gene expression in human colonic mucosa is elevated during early cancerogenesis. Steroids 66: 287-292, 2001.
76. Bareis P, Bises G, Bischof MG, Cross HS and Peterlik M: 25-hydroxy-vitamin d metabolism in human colon cancer cells during tumor progression. Biochem Biophys Res Commun 285: 1012-1017, 2001.

77. Bises G, Kállay E, Weiland T, Wrba F, Wenzl E, Bonner E, Kriwanek S, Obrist P and Cross HS: 25-hydroxyvitamin $\mathrm{D}_{3}$-1alpha-hydroxylase expression in normal and malignant human colon. J Histochem Cytochem 52: 985-989, 2004.

78. Brożyna AA, Jóźwicki W, Jochymski C and Slominski AT: Decreased expression of CYP27B1 correlates with the increased aggressiveness of ovarian carcinomas. Oncol Rep 33: 599-606, 2015.

79. Brożyna AA, Jóźwicki W, Janjetovic Z and Slominski AT: Expression of the vitamin D-activating enzyme 1 $\alpha$-hydroxylase (CYP27B1) decreases during melanoma progression. Hum Pathol 44: 374-387, 2013

80. Brown AJ and Slatopolsky E: Vitamin D analogs: Therapeutic applications and mechanisms for selectivity. Mol Aspects Med 29: 433-452, 2008

81. Kim TK, Wang J, Janjetovic Z, Chen J, Tuckey RC, Nguyen MN, Tang EK, Miller D, Li W and Slominski AT: Correlation between secosteroid-induced vitamin D receptor activity in melanoma cells and computer-modeled receptor binding strength. Mol Cell Endocrinol 361: 143-152, 2012. 